\title{
A new species of Bruggmanniella (Diptera, Cecidomyiidae, Asphondyliini) associated with Doliocarpus dentatus (Dilleniaceae) in Brazil
}

\author{
Valéria Cid Maiaํㅜ, G. Wilson Fernandes² \& Lázaro A. Oliveira²
}

${ }^{1}$ Depto. Entomologia, Museu Nacional, Quinta da Boa Vista, São Cristóvão, 20940-040 Rio de Janeiro-RJ, Brazil. maiavcid@acd.ufrj.br

\begin{abstract}
A new species of Bruggmanniella (Diptera, Cecidomyiidae, Asphondyliini) associated with Doliocarpus dentatus (Dilleniaceae) in Brazil. Bruggmanniella doliocarpi, a new galling species associated with Doliocarpus dentatus (Dilleniaceae) is described and illustrated (male, female, pupa, larva and gall) based on material from Minas Gerais, Brazil. The new species is compared to the other known Neotropical species. This is the first report of Bruggmanniella for Minas Gerais and in association with Dilleniaceae.
\end{abstract}

KEYWORDS. Brazilian savanna; gall midge; Neotropical; taxonomy.

RESUMO. Uma nova espécie de Bruggmanniella (Diptera, Cecidomyiidae, Asphondyliini) associada a Doliocarpus dentatus (Dilleniaceae) no Brasil. Bruggmanniella doliocarpi, uma nova espécie galhadora associada com Doliocarpus dentatus (Dilleniaceae) é descrita e ilustrada (macho, fêmea, pupa, larva e galha) com base em material coletado em Minas Gerais, Brasil. A nova espécie é comparada com as outras espécies neotropicais conhecidas. Esse é o primeiro registro de Bruggmanniella para Minas Gerais e em Dilleniaceae.

PALAVRAS-CHAVE. Cerrado; mosquito galhador; Neotropical; taxonomia.

Bruggmanniella Tavares, 1909 is known from ten galling species, seven Neotropical: B. braziliensis Tavares, 1909, B. byrsonimae (Maia \& Couri, 1992 in Maia et al. 1992), B. duguetiae Urso-Guimarães \& Amorim, 2004, B. ingae UrsoGuimarães \& Amorim, 2004, B. maytenuse (Maia \& Couri, 1992 in Maia et al. 1992), B. oblita Tavares, 1920, B. perseae Gagné, 2004; one southern Nearctic: B. bumeliae Felt, 1907; one Palaearctic: Bruggmanniella actinodaphnes Tokuda \& Yukawa, 2006; and one Oriental: Bruggmanniella cinnamomi Tokuda \& Yukawa, 2006 (Felt 1907; Gagné et al. 2004; Maia et al. 1992; Maia 1999, 2001; Tavares 1909, 1920; Tokuda \& Yukawa 2006; Urso-Guimarães \& Amorim 2004).

This genus is characterized by having three-segmented palpi; simple tarsal claws; male gonostyli with the tooth completely divided mesally, resulting in two separate teeth; female segment 8 with cerci-like lobes; well-developed pupal antennal horns; no frontal horns; tiny and numerous dorsal abdominal spines (from the anterior margin of the tergum to the row of dorsal papillae) and larval spatula four-toothed (Gagné 1994).

Each species of Bruggmanniella is associated with a different plant family (Table I). Species of Bruggmanniella induces galls on stems (B. actinodaphnes, $B$. braziliensis, $B$. cinnamomi, B. oblita, and B. duguetiae), twigs (B. bumeliae), flower buds (B. byrsonimae), ovaries (B. ingae), and fruits (B. perseae and B. maytenuse).

In this paper, a new species of Bruggmanniella that induces galls on stem of Doliocarpus dentatus Standtl. (Dilleniaceae) is described (larva, pupa, male and female) based on material collected from Minas Gerais (MG). This is the first report of
Bruggmanniella on Dilleniaceae and also the first record for Minas Gerais, Brazil.

Doliocarpus dentatus is a vine widely distributed in the low tropical rainforests of Mesoamerica, from southern Mexico to northern Peru, western Brazil, and northern Bolivia (Aponte et al. 2008). It also occurs in gallery forests, seasonally dry forests, and many formations of the cerrado (savanna), such as cerradão and cerrado "sensu stricto" (Sano et al. 2008) and has many medicinal and popular uses (see Skutch 1980; Sauvain et al. 1996; Rodrigues \& Carvalho 2001; Santos et al. 2002; Pinheiro et al. 2005; Aponte et al. 2008). Leaves are simple, petiole sometimes winged. The leaf blade is leathery, with the margin entire or serrate, elliptic or elliptic-lanceolate (for further detail, see Aymard 1997).

\section{MATERIAL AND METHODS}

Galls on Doliocarpus dentatus were collected in March 2008 in an area of cerrado (Brazilian savanna) vegetation near Ribeirão dos Porcos (19³0'25.6”'S; 4541'08.6’W), in the municipality of Dores do Indaiá, MG, Brazil at an altitude of $674 \mathrm{~m}$ a.s.l.

In the laboratory galls were placed in glass jars and left at environment temperature to await emergence of the galling adults. Some galls were dissected to collect immature stages of the inducer. Larvae, pupae and adults were prepared and mounted on slides following the methods of Gagné (1994). The gall midge genus was identified by using the key to Neotropical genera of Gagné (1994) and the species was determined as new after comparison with the original 
descriptions and illustrations, as well as comparison with specimens from the Diptera collection of the Museu Nacional (MNRJ). All material, including the types, was deposited in the Diptera collection of Museu Nacional, Rio de Janeiro (MNRJ). Morphological terminology follows Gagné (1994). The field and laboratory work was done by G.W. Fernandes and L. A. Oliveira, and the description of the new taxon was made by V.C. Maia.

\section{RESULTS}

\section{Bruggmanniella doliocarpi Maia sp. nov.}

(Figs. 1-14)

Adult. Body length: 5.0-5.3 mm in male ( $\mathrm{n}=3) ; 5.30 \mathrm{~mm}$ in female (from vertex to the distal margin of tergite $8, n=1$ ).

Head: eye facets hexagonal closely approximated. Antenna with scape obconic, pedicel globose, male flagellomeres 1-12 and female flagellomeres 1-11cylindrical with similar circumfila (Figs. 1 and 2). Female flagellomere 12 pyriform. Proportions of flagellomeres 9-12 as in Figures 3 and 4. Flagellomeres 1 and 2 connate. Frontoclypeus with 20-24 setae. Labrum triangular, long-attenuate, with three pairs of ventral setae. Hypopharynx of same shape as labrum with long, anteriorly directed lateral setulae. Labella elongateconvex, each with long lateral setae and three mesal setae. Palpus as in Figure 5.

Thorax: Wing: length from arculus to apex: $3.30-3.40 \mathrm{~mm}$ in male $(\mathrm{n}=3) ; 3.45 \mathrm{~mm}$ in female $(\mathrm{n}=1)$. Anepimeron setose. Other pleura bare. Tarsal claws with sexual dimorphism, simple on all legs; empodia as long as bend in claws in both sexes (Figs. 6 and 7).

Male abdomen: tergites 1-7 rectangular with single, complete row of caudal setae, some lateral setae, two basal trichoid sensilla and elsewhere with scattered scales. Tergite 8 unsclerotized, with only two basal trichoid sensilla as vestiture. Sternites 2-7 rectangular and setose, setae more abundant anteriorly and mesally, and two basal trichoid sensilla.

Sternite 8 rectangular, with scattered setae and scales from midlength to distal margin, and two basal trichoid sensilla. Male terminalia (Fig. 9): gonocoxite cylindrical, about 3.5 times longer than gonostylus; gonostylus ovoid, 0.082$0.085 \mathrm{~mm}$ of length, $0.059-0.061 \mathrm{~mm}$ of width $(\mathrm{n}=2)$, entirely setulose and with scattered setae, proportion gonostylus length/ width: 1.39-1.40; cercus wide, with setae and microsetulae, cercal lobes ovoid; hypoproct deeply bilobed, with setae and microsetulae; parameres absents; aedeagus narrow pointed at apex.

Female abdomen: tergites 1-7 as in male; tergite 8 notched laterally with a group of setae on distal half and two basal trichoid sensilla; sternites 2-6 as in male. Length of sternites 6 and 7: 0.35-0.39 mm, and 0.77-0.83 $\mathrm{mm}$, respectively $(\mathrm{n}=2)$. Seventh sternite about 2.14-2.2 length of preceding sternite, rectangular, more sclerotized at distal margin (Fig. 8), with scattered setae and two basal trichoid sensilla. Sternite 8 unsclerotized. Ovipositor length (rigid portion only): 1.28 $\mathrm{mm}(\mathrm{n}=1), 1.54-1.66$ as long as sternite 7.
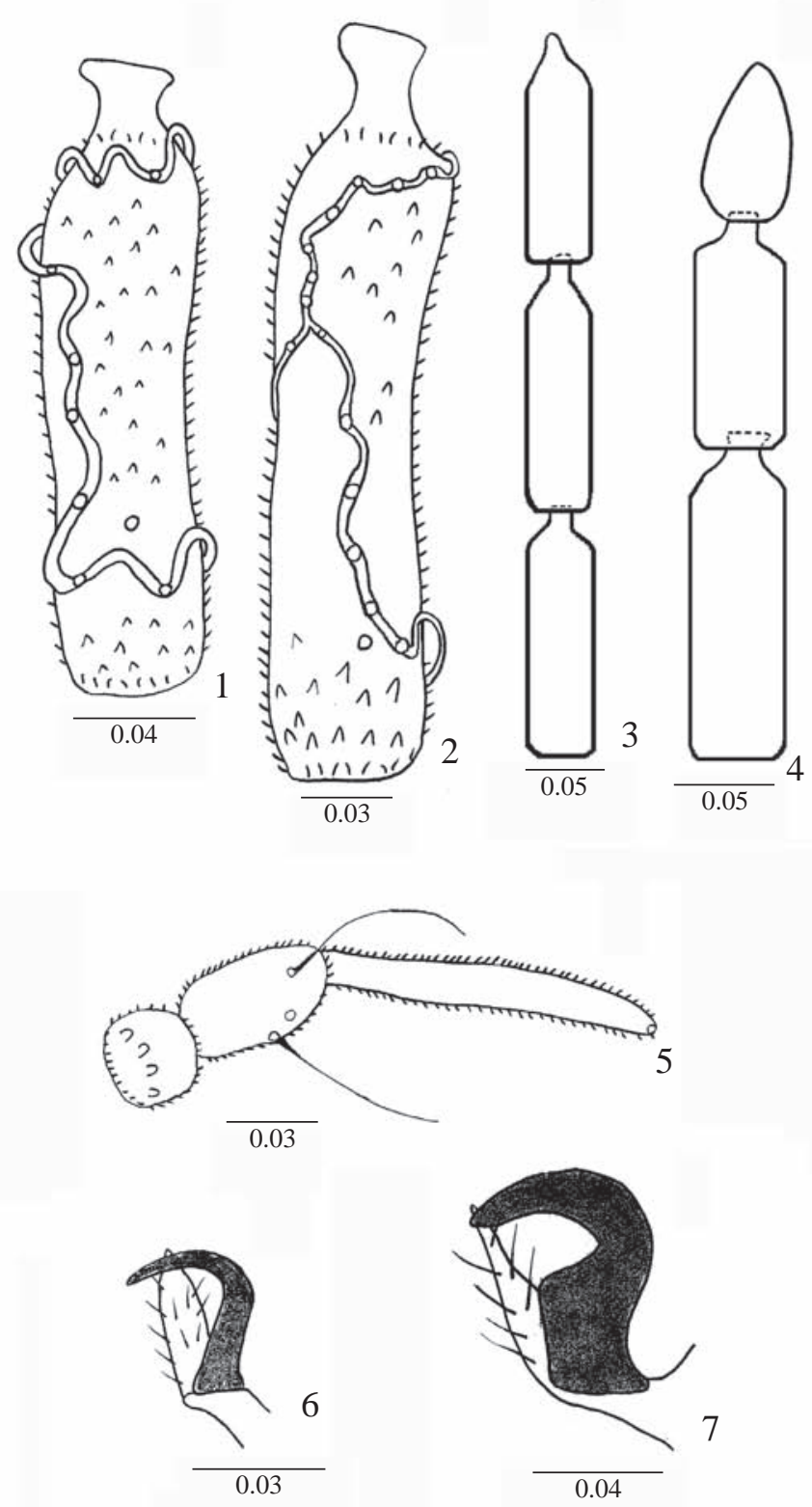

Figs. 1-7. Bruggmanniella doliocarpi sp. nov. 1, male flagellomere 5; 2. female flagellomere $5 ; 3$, male flagellomeres $9-12$; 4, female flagellomeres 9-12; 5, male palpus; 6, male foreleg and empodium, 7, female, midleg and empodium. Scales in $\mathrm{mm}$.

Pupa. Length: 5.3-6.2 mm (n=2). Head (Fig. 10): antennal horn triangular, serrate on edges, $0.38-0.44 \mathrm{~mm}$ of length $(\mathrm{n}=2)$; cephalic setae $0.04-0.05 \mathrm{~mm}$ of length $(\mathrm{n}=2)$; two pairs of lower lateral papillae (one setose and the other bare); three pairs of lateral papillae (two setose and one bare); upper facial margin thickened laterally. Prothoracic spiracle 0.31 $\mathrm{mm}$ long, cylindrical $(\mathrm{n}=3)$ (Fig. 11). Abdominal spiracles prominent on segments 3-8 (Fig. 12). Abdominal tergites 3-9 with dorsal spines (Fig. 13). Length of abdominal spiracle 5: 0.10-0.12 mm ( $\mathrm{n}=3)$.

Larva. Body length: 3.1-3.6 mm ( $\mathrm{n}=3)$. Integument rough. Spatula length: $0.32 \mathrm{~mm}(\mathrm{n}=1)$, width: $0.19 \mathrm{~mm}(\mathrm{n}=1)$; proportion spatula length/width: 1.7; inner teeth longer than 


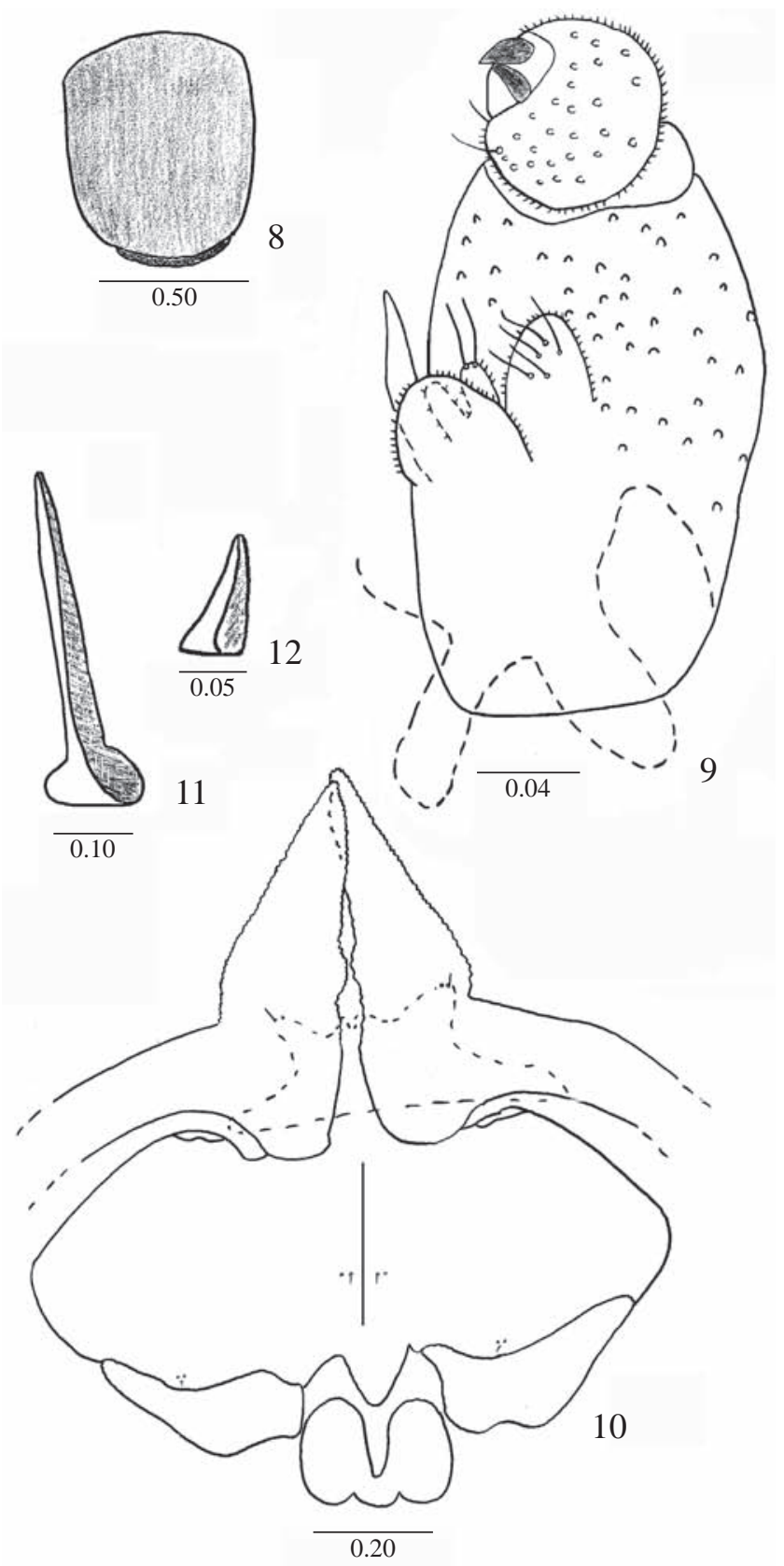

Fig. 8-12. Bruggmanniella doliocarpi sp. nov. 8, female, sternite 7; 9, male terminalia, dorsal view; 10, pupa head, frontal view; 11, pupa, prothoracic spiracle; 12, pupa, abdominal spiracle 7. Scales in mm.

the outer ones (length of inner teeth: $0.068 \mathrm{~mm}, \mathrm{n}=2$; length of outer teeth: $0.04 \mathrm{~mm}, \mathrm{n}=2$ ); three setose lateral papillae at each side (Fig. 14). Terminal segment without visible papillae.

Gall. Elliptical, on the stem, reddish with short trichomes on the gall walls, only one larva found inside the center of the sole chamber. Internal tissue of the gall is white and soft with a large content of water. Gall diameter is $18.01 \mathrm{~mm}$; may occur singly or in groups that vary from 2 to more then 100 along the stem. Adult emerges from a small hole positioned laterally in the gall wall. On the insertion point of the gall on the stem, a callus tissue is formed impairing any new induction of new galls (L. A. Oliveira, pers. obs.).
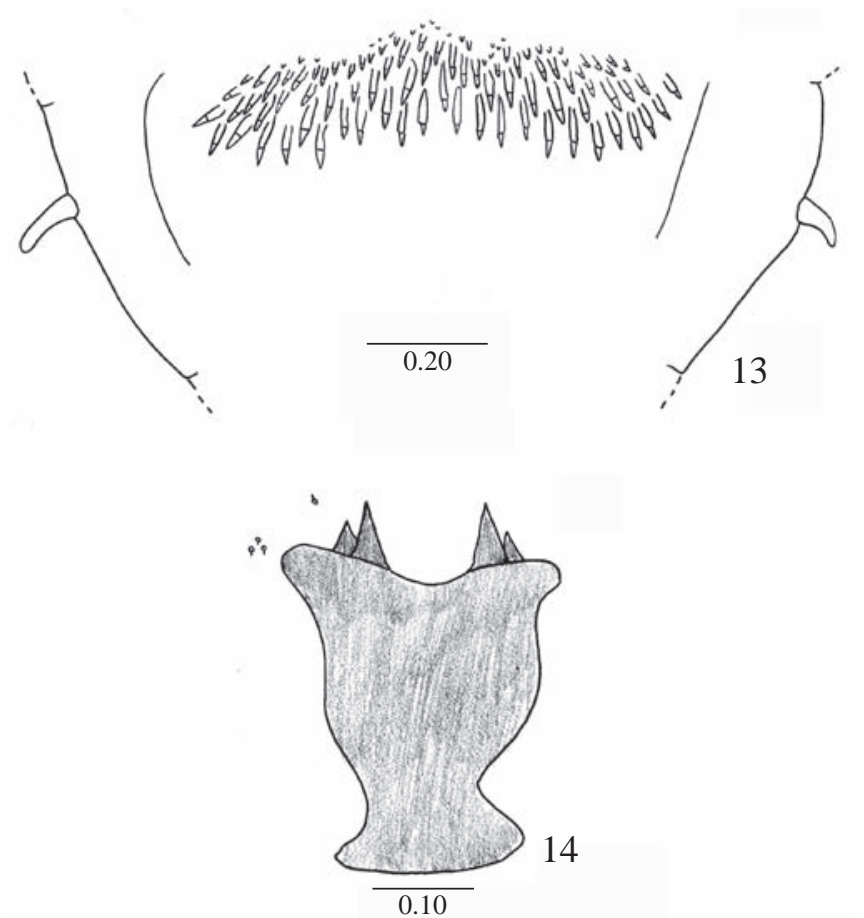

Figs. 13-14. Bruggmanniella doliocarpi sp. nov. 13, pupa, abdominal segment 7, dorsal view; 14, larva, spatula and papillae, ventral view. Scales in $\mathrm{mm}$.

Type material. Holotype male, Brazil, Minas Gerais: Dores do Indaiá, 20.IV.2008, L.A. Oliveira leg., MNRJ. Paratypes: same locality and collector, 21.IV.2008, 2 males, 2 females, 4 pupal exuviae and 3 larvae, MNRJ.

Etymology. The specific name is the genitive of the host plant generic name.

\section{DISCUSSION}

Bruggmanniella doliocarpi sp. nov. is distinctive for the following combination of characters: tubular base of the ovipositor, bilobed male hypoproct, wavy female antennal circumfila, sexually dimorphic tarsal claws, needlelike part

Table I. Distribution of the Bruggmanniella species per host plant (family and species).

\begin{tabular}{|c|c|c|}
\hline \multirow{2}{*}{ Galling species } & \multicolumn{2}{|r|}{ Host plant } \\
\hline & Family & Species \\
\hline B. actinodaphnes & Lauraceae & $\begin{array}{l}\text { Actinodaphne lancifolia (Sieb. } \\
\text { and Zucc.) }\end{array}$ \\
\hline B. braziliensis & Moraceae & Sorocea illicifolia Miq. \\
\hline B. bumeliae & Sapotaceae & $\begin{array}{l}\text { Bumelia lanuginosa (Michx.) } \\
\text { Pers. }\end{array}$ \\
\hline B. byrsonimae & Malpighiaceae & Byrsonima sericea DC. \\
\hline B. cinnamomi & Lauraceae & $\begin{array}{l}\text { Ciannamomum japonicum Sieb. } \\
\text { ex Nees. }\end{array}$ \\
\hline B. duguetia & Annonaceae & $\begin{array}{l}\text { Duguetia furduraceae (St. Hill.) } \\
\text { B. et H. }\end{array}$ \\
\hline B. ingae & Fabaceae & Inga edulis Mart. \\
\hline B. maytenuse & Celastraceae & Maytenus obtusifolia Mart. \\
\hline B. perseae & Lauraceae & Persea americana Miller \\
\hline B. oblita & Anacardiaceae & Schinnus sp. \\
\hline
\end{tabular}


of the ovipositor 1.54-1.66 times the length of the seventh sternite, long and microserrate antennal pupal horns, fourtoothed larval spatula with outer apical teeth shorter than the inner ones and reduced stalk.

Bruggmanniella doliocarpi sp. nov. was compared to the other Neotropical congeneric species. It differs from $B$. braziliensis and $B$. duguetiae mainly by the tubular shape of the base of the ovipositor (pyriform in these two species); and from $B$. maytenuse and $B$. ingae mainly in the bilobed shape of the hypoproct (simple in these two species). The female of $B$. doliocarpi sp. nov. differs from that of $B$. perseae in the shape of the antennal circumfila (wavy in the new species and slightly wavy in the latter) and of the tarsal claws (sexually dimorphic only in B. doliocarpi). Furthermore, the ratio between the length of needlelike part of the ovipositor and the length of the sternite 7 is longer in $B$. perseae than in the new species (ranging from 2.9-3.2 and 1.54-1.66 respectively).

At the immature stages, there are also differences. The pupa and larva of $B$. doliocarpi sp. nov. can be easily distinguishable from those of $B$. oblita by the long and serrate antennal pupal horns and the four-toothed larval spatula, while short and not serrate pupal horns and the three-toothed larval spatula in B. oblita.

The pupa of B. doliocarpi sp. nov. and B. byrsonimae have long and serrate antennal horns, but they are microserrate in $B$. doliocarpi and macroserrate in $B$. byrsonimae. Furthermore, the dorsal spines on abdominal segments 3-8 are conspicuously more numerous in B. byrsonimae. The larva of the new species differs from that of $B$. perseae in the shape of the spatula (the outer apical teeth are conspicuously shorter than the inner and the stalk is reduced in $B$. doliocarpi, while teeth of similar length and stalk not reduced in B. perseae).

Acknowledgements. We thank two anonymous reviewers for comments on an earlier version of the manuscript and to CNPq (30.9633/2007-9) for financial support.

\section{REFERENCES}

Aponte, J. C.; A. J. Vaisberg; R. Rojas; L. Caviedes, W. H. Lewis; G. Lamas; C. Sarasara; R. H. Gilman \& G. B. Hammond. 2008. Isolation of cytotoxic metabolites from targeted Peruvian Amazonian medicinal plants. Journal of Natural Products 71: 102-105.
Aymard, G. 1997. Dilleniaceae novae neotropicae, V. el género Doliocarpus en Colombia. Anales Del Jardín Botánico de Madrid 55: 17-30.

Felt, E. P. 1907. New species o Cecidomyiidae II. Albany, New York State Education Department, 23 p.

Gagné, R. J. 1994. The gall midges of the Neotropical region. Ithaca, Cornell University Press, 352 p.

Gagné, R. J.; F. Posada \& Z. N. Gil. 2004. A new species of Bruggmanniella (Diptera, Cecidomyiidae) aborting young fruit of avocado, Persea americana (Lauraceae), i Colômbia and Costa Rica. Proceedings of the Entomological Society of Washington 106: 547-553.

Maia, V. C. 1999. Descrição de imaturos de quatro espécies de Asphondyliini neotropicais e nota taxonômica sobre Asphondylia maytenuse Maia \& Couri (Cecidomyiidae: Diptera). Revista Brasileira de Zoologia 16: 775-778.

Maia, V. C. 2001. New genera and species of gall midges (Diptera, Cecidomyiidae) from three restingas of Rio de Janeiro State, Brazil. Revista Brasileira de Zoologia 18: 1-32.

Maia, V. C.; M. S. Couri \& R. F. Monteiro. 1992. Sobre seis espécies de Asphondylia Loew, 1850 do Brasil (Diptera, Cecidomyiidae). Revista Brasileira de Entomologia 36: 653-661.

Pinheiro, C. U. B.; V. M. dos Santos \& F.R.R. Ferreira. 2005. Amazônia: Ciência \& Desenvolvimento 1: 235-250.

Rodrigues, V. E. G. \& D. A. Carvalho. 2001. Levantamento etnobotânico de plantas medicinais no domínio do cerrado na região do Alto Rio Grande - Minas Gerais. Ciência Agrotécnica 25: 102-123.

Sano, S. M.; S. P. de Almeida \& J. F. Ribeiro. 2008. Cerrado: ecologia e flora. Embrapa Cerrados - Brasília, DF: EMBRAPA Informação tecnológica 2: 688.

Santos, S.A.; C. Costa; G. da Silva; A. Pott; J. M. Álvares \& S.R. Machado. 2002. Composição botânica da dieta de bovinos em pastagem nativa na sub-região da Nhecolândia, Pantanal. Revista Brasileira de Zootecnia 31: 1648-1662.

Sauvain, M.; N. Kunesch; J. Poisson; J. C. Gantier; P. Gayral \& J. P. Dedet. 1996. Isolation of leishmanicidal triterpenes and lignans from the amazonian liana Doliocarpus dentatus (Dilleniaceae). Phytotherapy Research 10: 1-4.

Skutch, A. F. 1980. Arils as food of Tropical American bird. Condor 82: 31-42.

Tavares, J. S. 1909. Contributio prima ed cognitionem cecidologiae Braziliae. Brotéria, Série Zoológica 8: 5-28.

Tavares, J. S. 1920. O gênero Bruggmanniella Tav. com a descripção de uma nova espécie e a clave dichotomica dos gêneros das Asphondyliariae. Brotéria, Série Zoológica 18: 33-42.

Tokuda, M. \& J. Yukawa. 2006. First records of genus Bruggmanniella (Diptera: Cecidomyiidae: Asphondyliini) from Palaearctic and Oriental regions, with descriptions of two new species that induce stem galls on Lauraceae in Japan. Annals of the Entomological Society of America 99: 629-637.

Urso-Guimarães, M. V. \& D. de S. Amorim. 2004. Two new species of Bruggmanniella Tavares, 1909 (Diptera, Cecidomyiidae) from Brazil. Studia Dipterologica 11: 429-436. 